\title{
The perceived capabilities and willingness of South African small business owners to act as business mentors
}

\author{
Melodi Botha* and Elriza Esterhuyzen \\ Department of Business Management, Economic and Management Sciences Building, Room 3-64, \\ Lynnwood Road, University of Pretoria, Pretoria, Republic of South Africa.
}

Accepted 30 May, 2012

\begin{abstract}
In this paper, it was determined whether South African small business owners have the capabilities to act as business mentors to potential or inexperienced entrepreneurs. Secondly, the willingness of South African small business owners to act as business mentors was determined. The literature study revealed that in order to perform the role of a successful business mentor requires particular personal, relational and professional capabilities. Willingness to act as a business mentor is influenced by a number of factors that need to be considered when deciding to perform such a role. The purpose of this paper was to provide an opportunity for interested groups to utilise small business owners as a source of business mentors to assist and guide inexperienced entrepreneurs through the difficult process of starting and growing a business. A measuring instrument was developed to field the perceptions of eighty respondents regarding their business mentoring capabilities and willingness to mentor. Factor analysis was conducted and the analysis of variance (ANOVA) was performed. The relationships between the respondents' rating of their mentoring capabilities (personal, relational and professional) and: their willingness to act as mentor; their previous engagement as a mentee; and their previous engagement as a mentor was determined.
\end{abstract}

Key words: Business mentors and mentees, capabilities and willingness to mentor.

\section{INTRODUCTION}

South Africa faces many economic, political and social challenges in its new democracy. One of the biggest challenges is that of growing unemployment, with a massive shortage of skilled and educated young people (Herrington et al., 2009: 12). The current unemployment rate for South Africa is $25.2 \%$ (Department of Statistics, 2012: vi).

Herrington et al. (2009: 12) further indicate that such unemployed and unemployable young people place a heavy burden on a limited government budget. The authors emphasise entrepreneurial and small business development as a means to create more business start-

*Corresponding author. E-mail: melodi.botha@up.ac.za. Tel: +2712420 4774 or 0836778472 . Fax: +27 123625198. ups. The poor success rate of business start-ups in South Africa relative to that of other countries underlines the need to support such entrepreneurs and to mentor entrepreneurs through the difficult process of starting and growing a business (Herrington et al., 2009: 62). Ladzani and Netswera (2009: 236) agree and state that one of the main factors contributing to the low success rate of small, medium and micro enterprises (SMMEs) in South Africa is the under-development and under-utilisation of business support services. Business mentoring is seen as one of the most important and effective business support services.

In terms of policy, the South African government regards SMMEs as vital role players in economic growth and development and job creation in this country [Department of Trade and Industry (DTI), 1995: 3]. The success of any SMME is directly related to the quality of 
the entrepreneur who starts and runs such a business.

The DTI regards business mentoring, in conjunction with training, as of extreme importance for small business owners to acquire relevant business skills, technical skills and vocational skills (DTI, 1995: 35-37). This study relates to the objectives set by the global entrepreneurship monitor report (Kelley et al., 2012: 8) which states the following: the need to identify factors that encourage entrepreneurship and make a contribution to stimulating entrepreneurship. Swanepoel et al. (2010: 75) concur that the very poor rate of SMME success in South Africa requires, inter alia, business mentoring to ensure successful business in South Africa and the realisation of government endeavours to reduce poverty and enhance employment. In order to assist emerging entrepreneurs to develop and run an SMME effectively, business mentors need to possess particular capabilities and the willingness to perform the role of business mentors.

Large numbers of South African business owners lack the ability to develop their businesses from start-up firms to established firms (Herrington et al., 2009: 148). The authors further suggest that business mentoring should focus on the formal sector, as small businesses in this sector create significantly more jobs and revenue than those in the informal sector.

Different authors indicate the capabilities needed to be business mentors (Moore et al., 2008: 21; Hisrich et al., 2008: 62). In the literature study of this paper, the capabilities of good business mentors were compiled into a profile and measured with regard to small business owners to determine whether they have these capabilities. It was, however, expected that even though small business owners might possess such capabilities, they might not be willing to act as business mentors for various reasons.

In light of the fact that business mentoring can play an important role in developing SMMEs, the question arises: To what extent do small business owners have the necessary capabilities and willingness to assist start-up entrepreneurs to make a success of their businesses? Furthermore, some reasons why South African small business owners are not willing to perform the role of business mentors for developing SMMEs are listed. Primary research was conducted to determine whether a group of small business owners had such capabilities and assess their willingness to act as business mentors. These capabilities were grouped into personal, relational and professional capabilities. The account of this is followed by analysis of collected data and related conclusions and recommendations.

\section{Problem investigated}

The South African government regards SMMEs as vital role players in economic growth and development, job creation and equity in the country (DTI, 1995: 3). The success of any SMME is directly related to the quality of the entrepreneur who starts and runs such a business. The successful development and management of SMMEs form an integral part of the job creation goals set by the South African government (Swanepoel et al., 2010: 59; Ladzani and Netswera, 2009: 225).

At present SMMEs do not meet such requirements, as evidenced by the fact that between $30 \%$ and $80 \%$ of businesses fail within the first two years of commencement (Pretorius, 2009: 309; DTI, 2000: 3). Many of the emerging entrepreneurs lack the necessary know-how to develop and manage their SMMEs effectively. Business mentoring could provide learning opportunities that focus on developing managerial and entrepreneurial skills and the capability of an emerging entrepreneur to grow a long-term, sustainable business (Adams, 2009: 194). Watson (2004: 2) underscores this by indicating that business mentorship nurtures and supports novice entrepreneurs by providing assistance that is renowned for professional, social and moral support.

If small business owners are willing to act as business mentors and capable of doing so, and they do not yet act as such, this is a huge untapped resource that could and should be utilised in order to help emerging entrepreneurs to grow successful businesses. This might ensure a higher success rate of SMMEs, which in turn might assist in alleviating the unemployment problem and poor economic situation in South Africa.

Current research findings in South Africa have concentrated on knowledge requirements for entrepreneurs and small business support practitioners (Martin, 2008: 24), as well as the situational analysis of entrepreneurship mentors (Watson, 2004: 8-9). None of these studies have homed in on small business owners' judgement of their own capabilities and willingness to act as business mentors. Therefore the problem statement is: To what extend are small business owners in South Africa willing to act as business mentors to inexperienced entrepreneurs? And secondly, to what extend do small business owners in South Africa have the capabilities to act as business mentors?

\section{Objectives of the study}

\section{Primary research objective}

The primary objective of this research is to establish the willingness of South African small business owners to act as business mentors.

\section{Secondary research objectives}

As indicated, the literature study revealed that the capabilities of business mentors can be grouped into personal, relational and professional capabilities. 
Therefore, as secondary objectives this study endeavours to prove the following:

1) Small business owners do have the personal capabilities needed to be good business mentors.

2) Small business owners do have the relational capabilities needed to be good business mentors.

3) Small business owners do have the professional capabilities needed to be good business mentors.

\section{Hypotheses}

The following null and alternative hypotheses are postulated:

$\mathbf{H}_{1:}$ South African small business owners do not have the willingness to act as business mentors.

$H_{1 A}$ : South African small business owners have the willingness to act as business mentors.

$\mathbf{H}_{2}$ : Small business owners do not have the personal capabilities needed to be good business mentors.

$\mathbf{H}_{2 \mathrm{~A}}$ : Small business owners do have the personal capabilities needed to be good business mentors.

$\mathbf{H}_{3}$ : Small business owners do not have the relational capabilities needed to be good business mentors.

$\mathbf{H}_{3 \mathrm{~A}}$ : Small business owners do have the relational capabilities needed to be good business mentors.

$\mathbf{H}_{4}$ : Small business owners do not have the professional capabilities needed to be good business mentors.

$\mathbf{H}_{4 \mathrm{~A}}$ : Small business owners do have the professional capabilities needed to be good business mentors.

\section{LITERATURE REVIEW}

In order to understand the concepts under study in the literature review it is necessary to briefly define a few concepts.

\section{Defining concepts}

Definitions of the main terms used in this paper follow.

\section{Small business and small business owners}

When defining small businesses, both qualitative and quantitative criteria need to be taken into consideration, according to the National Small Business Amendment Act, no 29 of 2004. This Act (2004: 1043) defines an enterprise as a separate and distinct business entity, together with its branches or subsidiaries, if any, including co-operative enterprises, managed by one owner or more predominantly carried on in any sector or subsector of the economy mentioned in column 1 of the Schedule and classified as a micro-, a very small, a small or a medium enterprise by satisfying the criteria mentioned in columns 3, 4 and 5 of the Schedule.

For the purposes of this paper, a small business will be regarded as one whose annual turnover does not exceed R10 million and which employs fewer than 50 employees.

\section{Entrepreneurship and the entrepreneur}

For the purposes of this paper, "entrepreneurship is the emergence and growth of new businesses.... Entrepreneurship is also the process that causes changes in the economic systems through innovations of individuals" (Nieman and Nieuwenhuizen, 2009:9). Making a profit that will serve a variety of needs is the basic motivation of entrepreneurial activities. Implementing the entrepreneurial process is essential for being a successful entrepreneur.

\section{Business mentoring}

Bettmann (2009: 1834) defines mentoring as a dynamic reciprocal relationship environment between an inexperienced mentee and an experienced business mentor, aimed at the development of the former. Business mentoring can be seen as a relationship between an experienced and inexperienced person, with the primary objective of supporting the personal and professional development of the junior person. The senior person coaches the junior in business skills to solidify self-confidence, and sponsors the junior by actively intervening in business situations in order to advance the professional qualities and opportunities of the junior (Robbins, 2001: 498).

\section{Business mentor}

Mincemoyer and Thomson (1998: 1) argue that a mentor can be regarded as a senior person of particular influence based on higher ranking with regard to experience and knowledge and who is committed to the professional advancement of less experienced persons. Osif (2008: 336) indicates that a mentor is a person with explicit applicable knowledge coupled with appropriate first-hand experience in a particular field of practice that a less experienced person would like to have. Generally it appears that a business mentor is a person who is willing to share his or her experiences, knowledge, know-how and skills, together with the solutions he or she has encountered in building a business and career successfully.

\section{Business mentee}

A mentee, also termed as protégé, is a person who has a limited background in a specific field of knowledge or 
discipline, coupled with limited experience in a specific field of practice and, therefore, limited professional expertise. Such limitations and inexperience may apply to business in general or to a specific type of business or career (Audet et al., 2006:5). Mentees, who may be of any gender, race or culture, are usually people of relatively younger age and in junior positions in organisations or those who have limited professional stature (Lankau et al., 2005: 257). Barrett (2006: 617) indicates that business mentees are people who participate in the mentoring process with the distinct motivation of improving their business skills. Business mentees appear to have a greater need for power and achievement (Clutterbuck, 2005: 6).

\section{Willingness}

Bergh (2004: 429) states that willingness implies the agreement to be involved in work. He also emphasises that it indicates a person's work orientation that relates to efficacy with regard to professional socialisation and achievements in performance. Willingness equates to being agreeable to cooperate (Robbins et al., 2006:88). Roythorne-Jacobs (2004: 204) corroborate this by stating that willingness implies agreeableness and cooperation.

For the purpose of this paper, willingness indicates a preparedness and commitment to perform the role of a business mentor. Willingness is demonstrated by being available and approachable to assist and support a startup mentee in developing personal and professional capacities and enhancing business success.

\section{Capability}

Capability reflects the capacity to perform a specific role on the basis of career maturity, which implies that a person has acquired the required knowledge, know-how, abilities and applicable attributes to perform specific responsibilities associated with a particular position (Bergh, 2004: 429). Robbins et al. (2006:47) state that capability indicates an individual's capacity to do and complete the responsibilities associated with a specific task. The distinct meaning of capability thus refers to what a person can do. Capability in this paper refers to the skills and competency needed in order to be a good or effective business mentor.

\section{Business mentoring capabilities}

An intensive literature review revealed that different authors put forward many different capabilities as necessary for business mentoring. Sambunjak et al. (2009: 75) classify desired characteristics of mentors in three groups. The three groups are personal, relational and professional capabilities; these capabilities are summarised in Table 1.

Personal capabilities refer to an individual's cognitive and behavioural competencies, implying the knowledge base and skills a person possesses as the basis for dealing with reality (Albertyn, 2004: 378). According to Sambunjak et al. (2009: 75), personal capabilities include understanding, patience, honesty, responsiveness, trustworthiness, non-judgemental attitude, reliability, and being an active listener and motivator.

Bettmann (2009: 1834) believes in the importance of relational capabilities and having interpersonal skills as an integral part of the capabilities needed by a business mentor. $\mathrm{He}$ also indicates that the success of the business mentoring relationship directly relates to the interest of the business mentor in serving as such. Interpersonal skills related to effective listening and empathy appear to be some of the strongest capabilities that a business mentor should possess. Building and maintaining a positive motivational and empowering working relationship will facilitate mentee growth in relationship building. Within the context of this paper it is important to understand that personal capabilities, interpersonal skills, and relational capabilities are closely interwoven and cannot be absolutely separated. With regard to the relational capabilities of a good business mentor, commitment to such a business mentoring relationship and availability to maintain this relationship is important (Clutterbuck, 2005: 4).

Sambunjak et al. (2009: 75) regard professional capabilities of the business mentor as the mentor being senior and well-respected, and knowledgeable and experienced in the business context. Sufficient skills related to the specific business of the mentee are very important (Bettmann, 2009: 1834). In this regard, the business mentor needs to set the example as a role model for the mentee. Acting as a role model also applies to the wide range of capabilities of the business mentor which need to be imparted to the mentee during the mentoring process. Hegarty and Styles (2008: 22) specify that being a role model for the business mentee implies the demonstration of appropriate professional behaviour. Mentees master applicable attitudes, behaviours, values, and roles by emulating, observing and imitating the examples that their business mentors set (Audet et al., 2006: 56).

\section{Willingness to act as business mentor}

Willingness to act as a business mentor refers to a positive approach towards the business mentoring of an inexperienced mentee with a view to assisting and guiding the latter on the way to becoming a mature, effective business owner. Table 2 refers to the various factors that can play a role in the decision of an experienced business owner to take up the role and 
Table 1. Summary of business mentor capabilities.

\begin{tabular}{|c|c|c|}
\hline Capability & Brief explanation of the capability & Source \\
\hline \multicolumn{3}{|l|}{ Personal capability } \\
\hline Ability to inspire people & $\begin{array}{l}\text { Motivate, instil sense of purpose, desire to succeed, positive } \\
\text { attitude, client orientation }\end{array}$ & $\begin{array}{l}\text { Swanepoel et al. (2010: 66) and Lamm and Harder } \\
(2010: 3)\end{array}$ \\
\hline Ability to begin where mentee is & $\begin{array}{l}\text { Enter mentee's world, understand experiences and } \\
\text { challenges, culture and language }\end{array}$ & Audet et al. (2006: 4) and Sambunjak et al. (2009: 75) \\
\hline Empathy & $\begin{array}{l}\text { Appreciate feelings, experiences and frustrations, be non- } \\
\text { judgemental }\end{array}$ & $\begin{array}{l}\text { Audet et al. (2006: 4), Gehrke (1988: 194), Lamm and } \\
\text { Harder (2010: 3) and Clutterbuck (2005: 4) }\end{array}$ \\
\hline Belief in mentee & Create confidence, see bigger picture & Thompson and Downing (2007:537) \\
\hline Effective, active listening skills & Hear and understand the 'language' of mentee & Audet et al. (2006: 4) and Clutterbuck (2005: 4) \\
\hline $\begin{array}{l}\text { Reflection and teaching by giving } \\
\text { feedback }\end{array}$ & $\begin{array}{l}\text { Use analytical, systematic and conceptual thinking and gain } \\
\text { perspective thereby; use problem-solving }\end{array}$ & Freedman (2009: 173) \\
\hline Credibility, trustworthiness and integrity & Adhere to personal moral values & $\begin{array}{l}\text { Benn and Brennand (2008: 2), Sullivan (2000: 171) and } \\
\text { Lamm and Harder (2010: 3) }\end{array}$ \\
\hline Communication skills & $\begin{array}{l}\text { Congruently understand language of mentee and ensure } \\
\text { congruency of own language }\end{array}$ & $\begin{array}{l}\text { Dalley and Hamilton (2000: 10), Terrion and Leonard } \\
\text { (2007: 156), Erasmus et al. (2006: 248) and Pinho et al. } \\
\text { (2005: 21) }\end{array}$ \\
\hline Supportiveness & $\begin{array}{l}\text { Recognise progress of mentee, give recognition and share in } \\
\text { achievements }\end{array}$ & $\begin{array}{l}\text { Thompson and Downing (2007: 537), Benn and } \\
\text { Brennand (2008: 2) and Benard (1998: 2) }\end{array}$ \\
\hline Selflessness & Put other's interests before one's own & Bettmann (2009: 1834) and Clutterbuck (2005: 4) \\
\hline \multicolumn{3}{|l|}{ Relational capability } \\
\hline Accessibility & Be approachable and make time available & Derrida (2009: 2) and Sambunjak et al. (2009: 5) \\
\hline Ability to build long-term relationship & $\begin{array}{l}\text { Create and maintain a workable, practicable relationship over } \\
\text { time }\end{array}$ & $\begin{array}{l}\text { Rickard and Rickard (2009: 767), Barrett (2006: 615) } \\
\text { and Erdem and Janset (2008: 4) }\end{array}$ \\
\hline Interpersonal skills & $\begin{array}{l}\text { Work and liaise with other people in an easy, acceptable } \\
\text { manner for the purpose of building a relationship }\end{array}$ & Gibb (2000:16) and Hegarty and Styles (2008: 24) \\
\hline Commitment & $\begin{array}{l}\text { Dedicate oneself on a long-term basis in order to achieve } \\
\text { personal and professional goals }\end{array}$ & Clutterbuck (2005: 4) and Bettmann (2009: 1834) \\
\hline
\end{tabular}


Table 1.Contd.

\begin{tabular}{|c|c|c|}
\hline \multicolumn{3}{|l|}{ Professional capability } \\
\hline Business experience & Be a practical 'how-to', expert in field of business & Sambunjak et al. (2009: 75) and Audet et al. (2006: 11) \\
\hline Business knowledge & $\begin{array}{l}\text { Communicate perspectives on the what, where, when, why, who } \\
\text { and how of developing a business }\end{array}$ & Hisrich et al. (2008: 62) \\
\hline $\begin{array}{l}\text { Ability to see opportunities } \\
\text { and challenges }\end{array}$ & $\begin{array}{l}\text { Understand the risks in the entrepreneurial process and generate } \\
\text { solutions }\end{array}$ & Benn and Brennard (2008: 2) \\
\hline Training skills & Facilitate mentee learning & $\begin{array}{l}\text { Barrett (2006: 23), Gibb (2000: 16), Bozeman and } \\
\text { Feeney (2008: 475) and Audet et al. (2006: 5) }\end{array}$ \\
\hline $\begin{array}{l}\text { Goal setting and planning } \\
\text { skills }\end{array}$ & Elicit feasible objectives and foresee ways of achieving them & Clutterbuck (2005: 5) \\
\hline Problem-solving abilities & $\begin{array}{l}\text { Generate solutions in relation to obstacles and challenges in the } \\
\text { entrepreneurial process }\end{array}$ & Watson (2004:154) and Lamm and Harder (2010: 3) \\
\hline Decision making & $\begin{array}{l}\text { Come to applicable valid conclusions related to specific } \\
\text { challenges }\end{array}$ & Sullivan (2000:167) \\
\hline Ability to be a role model & Set a clear example of professional conduct & $\begin{array}{l}\text { Hegarty and Styles (2008: 2), Erdem and Janset (2008: } \\
\text { 4), Derrida (2009: 2), Robbins et al. (2006: 56), Barrett } \\
\text { (2006:23) and Hisrich et al. (2008: 62) }\end{array}$ \\
\hline Ability to evaluate & $\begin{array}{l}\text { Assess mentee achievements in mastering learning objectives } \\
\text { and outcomes }\end{array}$ & Audet et al. (2006: 5) \\
\hline Strategic vision & $\begin{array}{l}\text { Appraise current business affairs in the light of future threats with } \\
\text { a view to ensuring success }\end{array}$ & Dracup and Bryan-Brown (2004: 450) \\
\hline Risk-taking abilities & $\begin{array}{l}\text { Judge the threats within a given business opportunity and make } \\
\text { effective, realistic decisions for achieving success }\end{array}$ & Dracup and Bryan-Brown (2004: 450) \\
\hline Creativity & $\begin{array}{l}\text { Generate innovative ways of utilising opportunities and resources } \\
\text { for advantageous business successes }\end{array}$ & Dracup and Bryan-Brown (2004: 450) \\
\hline Leadership & $\begin{array}{l}\text { Provide positive and appreciative direction with regard to } \\
\text { performing professional responsibilities }\end{array}$ & Clutterbuck (1999: 76) and Erdem and Janset (2008: 4) \\
\hline
\end{tabular}

Source: Own compilation. 
Table 2. Factors influencing willingness to act as a business mentor.

\begin{tabular}{lll}
\hline Factor & Short description & Source \\
\hline Demographic similarity & Geographical distance & Lankau et al. (2005: 262) \\
Deep-level similarity & Emotional congruency & Lankau et al. (2005: 262) \\
Functional similarity & Undertaking similar tasks/responsibilities & Lankau et al. (2005: 262) \\
Limited loyalty to a particular employer & Not bound by organisational structures & Lankau et al. (2005: 262) \\
Interpersonal attraction & Liking and cohesion & Lankau et al. (2005: 262) \\
Previous experience of mentoring & Having been previously involved as mentor & Ghislieri et al. (2009: 207-209) \\
Self-directed individual & Internal locus of control & Ghislieri et al. (2009: 207-209) \\
Gender & Male persons more likely to mentor & Ghislieri et al. (2009: 207-209) \\
Benefits for mentors & Rewards, building stature, self-efficacy etc. & Ghislieri et al. (2009: 207-209) \\
Mentee interpersonal competence & Effective social skills & Pinho et al. (2005: 21) \\
Mentee subordinance & Mentee willingness to accept authority & Pinho et al. (2005: 21) \\
Mentor personal and professional interest & Self-improvement & Pinho et al. (2005: 21) and Sambunjak et al. (2009:75) \\
\hline Source: Own compilation & &
\end{tabular}

responsibilities of business mentoring (Ghislieri et al. 2009: 216-217; Lankau et al., 2005: 264).

Ghislieri et al. (2009: 207-209) used seven scales to measure mentoring variables: willingness to mentor, perceived drawbacks to mentoring, organisational support for mentoring, mentoring functions, mentoring benefits, mentoring costs and personal characteristics perceived as necessary for a mentor. They presented the following results:

1) Male persons are more willing to mentor.

2) Executives are more willing to mentor than manual workers, office workers and supervisors.

3) Differences in educational levels do not play a role in willingness to mentor.

4) Non-executives list more drawbacks to mentoring than executives, as do less welleducated persons in comparison with more highly educated persons.
5) People who have had previous experience as a mentor are more willing to mentor and list fewer drawbacks to mentoring.

6) Positive innate and acquired personal characteristics and past mentoring satisfaction are positively related to willingness to mentor.

7) Willingness to mentor relates to mentoring benefits, mentoring costs, mentoring functions, self-efficacy, ambition and self-determination, and sensitivity to control by others.

Pinho et al. (2005: 21) indicate that willingness to mentor is influenced by the mentor's perceptions about the mentee's interpersonal competence and willingness to accept authority. Similarity with regard to personal and professional interest and expectations also play a role in willingness to mentor (Sambunjak et al., 2009: 75; Pinho et al., 2005: 21). Table 2 provides a summary of the factors that influence an individual to act as a business mentor.

\section{RESEARCH METHODOLOGY}

\section{Research design}

Quantitative research was conducted by collecting data from a self-developed measuring instrument which was distributed to small business owners. This ties in with the findings of Allen et al. (2008: 248, 353), in their study on the state of research on mentoring, that such an approach is the most prevalent $(89.9 \%)$. The study did not apply a standardised measuring instrument, as such instruments pertaining to the profiling of the capabilities or willingness of small business owners to act as business mentors did not exist (Ghislieri et al., 2009: 210).

The respondents had to rate their capabilities and willingness to act as business mentors on a three-point Likert-rating scale. Open-ended unforced choice rating scale measures were few. The measurement scales include nominal, ordinal and ratio types of scale (Cooper and Schindler, 2008: 282-286). Additionally, factor 
analysis was executed to determine the validity of the different Likert scale items used throughout the measuring instrument. Cronbach alpha values were determined to provide the reliability coefficients calculated for the final factors of the Likert scales used in the measuring instrument. The ANOVA was used to determine possible differences between perceptions of the sample with regard to personal, relational and professional capabilities.

\section{Research population}

Cooper and Schindler (2008: 374 ) define a research population as all the elements (South African small business owners in this study) about which a researcher intends to make inferences. Diamantopoulos and Schlegelmilch (2000: 10) elicit a population to be the 'totality of entities'. The questionnaire was distributed to 90 small business owners from all industries, of which 80 returned the completed measuring instrument. This represents $89 \%$ response rate. A non-probability convenience sampling technique was used because the total population (which would have been all small business owners) was not available and accessible (Cooper and Schindler, 2008: 397). Such sampling implies that findings do not ipso facto apply to all small business owners in a particular society. A snowballing and referral technique was used to mine the network for the research (Pellisier, 2007: 32).

\section{Sampling selection and size}

Eighty South African small business owners in the Gauteng Province were included in the sample. As indicated in the National Small Business Amendment Act (2004: 1043) a small business implied an annual turnover of less than R10 million with less than 50 employees.

\section{FINDINGS}

\section{Demographic information}

The demographic composition of the eighty small business owners in this study comprised $48(60 \%)$ male and $32(40 \%)$ female respondents. This represents a respondent ratio between females and males of 1:1.5. The global entrepreneurship monitor (GEM) report (Kelley et al., 2012:22) indicates that the ratio of females to males involved in entrepreneurial ventures is 1:1.6. The ages of the respondents ranged from 21 to 70 years, with the average age being 43 years. This finding relates favourably to the group of 35 to 44 years old who contribute mostly to entrepreneurship in South Africa (Kelley et al., 2012: 23). Five (6.25\%) black respondents participated in this study. Only one respondent $(1.25 \%)$ came from the Indian race, while $73(91.25 \%)$ came from the white (Caucasian) community and the Chinese group was represented by one respondent (1.25\%).

This study was limited to the geographical areas of Pretoria, Johannesburg, the Vaal Triangle, East Rand and West Rand areas. These areas form the core of the Gauteng Province, which make up the largest proportion of the South African population (Department of Statistics, 2011:2). The majority of the respondents (73 respondents or $91 \%$ ) resided in the Pretoria area. Regarding the period of ownership of a business, the majority, 55 respondents $(68.75 \%)$, indicated that they had owned their businesses for 10 years or less. In total, 73 respondents (91.25\%) had owned businesses for a period of up to 20 years. The businesses owned were classified in nine (9) different industry types. The majority, 30 respondents $(37.5 \%)$, resorted in the 'services' group, followed by the 21 respondents (or 26.25\%) whose businesses belonged to the 'retail' industry.

Data indicated that more than three-quarters, 63 respondents $(78.75 \%)$ had had no experience with regard to being mentored as a mentee within a business context. Only 17 respondents $(21.25 \%)$ had had experience in this regard. The majority, 53 respondents $(66 \%)$ had no previous experience of acting as a business mentor, with the remaining 27 respondents (34\%) having performed such role previously.

\section{Information on respondents' capabilities}

Respondents were asked to rate themselves according to their business mentor capabilities. The majority of the respondents rated themselves as 'good' in more than $63 \%$ of the total list of capabilities. The capability that received the highest rating of all was the relational capability of commitment, which was higher than $80 \%$. The capability that received the lowest ranking (lower than $12 \%$ ) was the relational capability of accessibility. In only seven $(26 \%)$ of the total list of twenty-seven capabilities did the respondents rate their highest level of capability as 'average'. In three of the four of the listed relational capabilities, more than $66 \%$ of the respondents rated themselves as 'good.' The majority of respondents rated themselves as 'good' in ten of the thirteen professional capabilities that were structured.

In general, the majority of the respondents rated themselves fairly positively pertaining to most of the personal, relational and professional capabilities that are important for a business mentor to make a success of a business mentoring relationship.

\section{Empirical results indicating the respondents' willingness to act as a business mentor}

The majority, 46 respondents (57\%) indicated an unwillingness to act as business mentors towards business mentees. The remaining 34 respondents (43\%) indicated that they would be willing to act as business mentors. The 46 respondents (57\%) who were unwilling to act as business mentor listed time constraints $(76 \%$ respondents indicated this reason) as a reason for their unwillingness.

Frequency of interaction and contact play an important role in making a business mentoring relationship successful. Out of the 34 respondents (43\%) who indicated willingness to act as business mentors, almost $80 \%$ (27 out of the 34 ) were willing to spend up to 
$5 \mathrm{~h}$ per week on business mentoring. It was clearly indicated in this study that an important aspect of business mentoring lies in the fact that it has to be in the form of a relationship. Most (almost 40\%) of the respondents who were willing to act as business mentors were prepared to be involved for a period of up to six months.

The majority (90\%) of the respondents (42 out of the 46 respondents) indicated that they would be willing to engage in cross-cultural business mentoring, while $88 \%$ (40 out of the 46) were in favour of cross-gender mentoring.

\section{Confirmation of the validity and reliability of the measuring instrument}

\section{Factor analysis}

Factor analysis using direct quartimin (oblique) rotation was performed in order to reduce the large number of variables pertaining to business mentoring capabilities to a smaller, more manageable set of factors. Loading of variables was done. The resulting eigen values which were greater, or equal to 1 , were 8 in total. For the purpose of this paper, the highest three Eigen values were included as factors. The eigen value for factor one (1) is 8.07180 , for factor two (2) it is 2.06408 and for factor three (3) it is 1.67112 . Eigen values present an estimate of the total amount of variance which a factor explains. Factor 1 therefore explains $10 \%$ of the variance, factor 2 explains $33 \%$ and factor 3 explains $38 \%$. The following three factors were found and were labelled as follows:

Factor 1: Relational and professional capabilities

Factor 2: Personal capabilities

Factor 3: Business experience and knowledge

Cronbach alpha reliability values were calculated for the three factors. According to a study conducted by Athayde (2003: 10) regarding acceptable alpha scores, an acceptable score ranges from 0.600 to 0.999 . For the purposes of this study, a Cronbach Alpha result of more than 0.6 was regarded as meaningful internal consistency. Table 3 shows the results in this regard as applied to the three factors earlier mentioned.

In order for the researchers' to achieve the stated research objectives, the relationship between the respondents' willingness to mentor, their previous engagement as a mentor or as a mentee and their mentoring capabilities was investigated.

Relationship between willingness to mentor, previous engagement as a mentor and mentee and mentoring capabilities

The preceding explanation gave the results of the factor analysis in which three factors were compiled: relational and professional capabilities, personal capabilities and business experience and knowledge. For the purposes of this study, it was decided to perform inferential statistical techniques on the original three groups as identified in the literature study.

To investigate the relationship between the respondents' willingness to act as business mentors and their ratings of their business mentoring capabilities, an analysis of variance (ANOVA) was performed to determine whether the rating of respondents on their mentoring capabilities differed in terms of the variables: willingness to act as mentor, their previous experience as mentee and/or their previous experience as mentor. This area presents first the personal mentoring capabilities and the mentioned relationships; then the relational mentoring capabilities and the mentioned relationships and finally the professional capabilities and the mentioned relationships. The results of the relationship between the ratings of the respondents' personal mentoring capabilities and their willingness to act as business mentor and their previous experiences in a mentoring relationship (as mentor or mentee) are depicted in Table 4 (ANOVA) and Table 5 (mean and standard deviations).

The results show that the respondents who were willing to act as business mentors had a statistically significantly (on the $5 \%$ level) higher rating of their personal mentoring capabilities than the respondents who were not willing to act as business mentors. There were no significant differences between the respondents who had been mentored previously and those who had not. Similarly, respondents who had mentored before did not differ significantly from those who had not.

The results show that the respondents who were willing to act as business mentors rated themselves higher on personal mentoring capabilities than those who were unwilling to do so (mean scores indicate 2.58 versus 2.38). This may imply that the positive perceptions of their personal mentoring capabilities of the respondents who were willing to act as business mentors had a positive influence on their willingness to act as business mentors. By implication, it may also indicate that respondents who were unwilling to act as business mentors rated themselves lower on their personal mentoring capabilities.

The relationships between the rating of the respondents' relational mentoring capabilities and their willingness to act as business mentors and their previous experiences in a mentoring relationship (as mentor or mentee) are depicted in Table 6 (ANOVA) and Table 7 (mean and standard deviations).

Table 6 indicates that no statistically significant difference level ( $p$-value of less than 0.05) was found regarding relational mentoring capabilities and willingness to act as business mentor. Likewise, no statistically significant difference level was indicated between respondents' rating of their relational mentoring capabilities 
Table 3. Cronbach alpha results for business mentoring capabilities.

\begin{tabular}{llc}
\hline Factor & Description of factor & Cronbach alpha value \\
\hline Factor 1 & Relational and professional capabilities & 0.8352 \\
Factor 2 & Personal capabilities & 0.7348 \\
Factor 3 & Business experience and knowledge & 0.7365 \\
\hline
\end{tabular}

Table 4. Personal capabilities: Results of ANOVA.

\begin{tabular}{lccc}
\hline Variable & DF & F Value & Pr $>$ F \\
\hline Would you be willing to act as a business mentor? & 1 & 5.32 & $0.0238^{*}$ \\
Have you ever been mentored by a business mentor (in a business context)? & 1 & 0.50 & 0.4826 \\
Have you ever performed the role of a business mentor before? & 1 & 0.04 & 0.8459 \\
\hline
\end{tabular}

*Significance on $5 \%$ level.

Table 5. Personal capabilities: Mean and standard deviations.

\begin{tabular}{lcc}
\hline Variable & \multicolumn{2}{c}{ Personal capability } \\
\hline Would you be willing to act as a business mentor? & Mean & Standard deviation \\
\hline Yes & 2.58 & 0.33 \\
No & 2.38 & 0.33 \\
Have you ever been mentored by a business mentor? & & \\
Yes & 2.54 & 0.31 \\
No & 2.44 & 0.35 \\
Have you ever performed the role of a business mentor before? & & \\
Yes & 2.53 & 0.34 \\
No & 2.43 & 0.35 \\
\hline
\end{tabular}

and previous experience as a business mentor. Moreover, no statistically significant difference was found between respondents' rating of their relational mentoring capabilities and their previous experience as a business mentee $(p>0.05)$.

It was deduced that respondents' rating of their relational mentoring capabilities showed no relationship to their willingness to act as business mentors, or their previous experience as business mentors or business mentees.

The relationship between the rating of the respondents' professional mentoring capabilities and their willingness to act as business mentor and their previous experiences in a mentoring relationship (as mentor or mentee) is depicted in Table 8 (ANOVA) and Table 9 (mean and standard deviations).

The results show that the respondents who were willing to act as business mentors had a statistically significantly (on the $10 \%$ level) higher rating of their professional mentoring capabilities than the respondents who were not willing to act as business mentors. There were no significant differences between the respondents who had been mentored previously and those who had not. Similarly, respondents who had mentored before did not differ significantly from those who had not.

The results further indicate that the respondents who were willing to act as business mentors rated themselves higher on professional mentoring capabilities than those who were unwilling to do so (the mean scores indicate, 2.62 versus 2.44 ). This may imply that the positive rating of their professional mentoring capabilities by the respondents who were willing to act as business mentors had a positive influence on their willingness to act as business mentors. By implication, it may also indicate that respondents who were unwilling to act as business mentors rated themselves lower on their professional mentoring capabilities.

\section{DISCUSSION OF FINDINGS}

The results of this study indicate that the majority of respondents considered that they possessed most of the personal, relational and professional capabilities needed 
Table 6. Relational capabilities: Results of ANOVA.

\begin{tabular}{lccc}
\hline Source & DF & F Value & Pr $>$ F \\
\hline V37 - Would you be willing to act as a business mentor? & 1 & 1.80 & 0.1833 \\
V8 - Have you ever been mentored by a business mentor (in a business context)? & 1 & 0.29 & 0.5932 \\
V9 - Have you ever performed the role of a business mentor before? & 1 & 0.02 & 0.8952 \\
\hline
\end{tabular}

Table 7. Relational capabilities: Mean and standard deviations.

\begin{tabular}{lcc}
\hline Variable & \multicolumn{2}{c}{ Relational capability } \\
\hline Would you be willing to act as a business mentor? & Mean & Standard deviation \\
\hline Yes & 2.66 & 0.31 \\
No & 2.54 & 0.40 \\
Have you ever been mentored by a business mentor? & & \\
Yes & 2.65 & 0.39 \\
No & 2.58 & 0.36 \\
Have you ever performed the role of a business mentor before? & & \\
Yes & 2.62 & 0.36 \\
No & 2.58 & 0.37 \\
\hline
\end{tabular}

Table 8. Professional capabilities: Results of ANOVA.

\begin{tabular}{lccc}
\hline Source & DF & F Value & Pr $>$ F \\
\hline V37 - Would you be willing to act as a business mentor? & 1 & 3.91 & $0.0517^{*}$ \\
V8 - Have you ever been mentored by a business mentor (in a business context)? & 1 & 0.25 & 0.6155 \\
V9 - Have you ever performed the role of a business mentor before? & 1 & 0.20 & 0.6590 \\
\hline
\end{tabular}

*Significance on $10 \%$ level.

Table 9. Professional capabilities: Mean and standard deviations.

\begin{tabular}{|c|c|c|}
\hline Variable & \multicolumn{2}{|c|}{ Professional capability } \\
\hline Would you be willing to act as a business mentor? & Mean & Standard deviation \\
\hline Yes & 2.62 & 0.27 \\
\hline No & 2.44 & 0.41 \\
\hline \multicolumn{3}{|l|}{ Have you ever been mentored by a business mentor? } \\
\hline Yes & 2.58 & 0.26 \\
\hline No & 2.49 & 0.39 \\
\hline \multicolumn{3}{|c|}{ Have you ever performed the role of a business mentor before? } \\
\hline Yes & 2.58 & 0.34 \\
\hline No & 2.48 & 0.37 \\
\hline
\end{tabular}

to act as business mentors. Despite the high perceptions regarding their business mentoring capabilities, only $43 \%$ of respondents indicated a willingness to act as business mentors. Therefore, the null hypothesis was accepted $\left(\mathrm{H}_{1}\right.$ - South African small business owners do not have the willingness to act as business mentors), and the alternative hypothesis rejected.

Based on the conducted tests and empirical results, the forth-flowing null hypotheses $\left(\mathrm{H}_{2}, \mathrm{H}_{3}\right.$, and $\left.\mathrm{H}_{4}\right)$ were rejected, and the alternative hypotheses (small business 
owners do have the personal capabilities needed to be good business mentors, small business owners do have the relational capabilities needed to be good business mentors and small business owners do have the professional capabilities needed to be good business mentors) were accepted. Regarding the acceptance and rejection of the stated hypotheses, many relationships were tested between the respondents' willingness to act as business mentors, their various business mentoring capabilities and previous engagements as business mentors and/or mentees.

\section{Conclusion}

Generally it appears that, although the majority of South African small business owners who participated in this study did not see their way open to act as business mentors, mainly owing to lack of time, a substantial percentage (> 40\%) were willing to do so for a period of at least six months, to the extent of up to five hours per week and within a cross-cultural and cross-gender context.

The ANOVA indicated on a $5 \%$ level of significance that the perceived personal capabilities of South African small business owners plays a role in their willingness to act as business mentors, and a statistically significant difference was obtained between the variables. Relational capabilities had no such effect. Regarding professional capabilities, the ANOVA showed on a $10 \%$ level of significance that such capabilities influenced the willingness to act as business mentors. Therefore, inferential statistics revealed a positive relationship between perceived business mentoring capabilities and willingness to act as business mentors.

No significant relationship was found between the perceived personal, relational and professional capabilities of South African small business owners and their previous experiences as a business mentor or business mentee.

\section{Implications for managers / recommendations}

As indicated by Herrington et al. (2009: 62), the poor success rate of business start-ups in South Africa relative to that of other countries means we need to develop policy interventions giving support to such entrepreneurs. Interventions should be aimed at mentoring entrepreneurs through the difficult process of starting and growing a business. In the researchers' opinion after conducting this study, South African small business owners is an untapped resource that should be utilised in order to encourage and support these entrepreneurs by business mentoring. Additionally, if the perceived rewards gained from acting as business mentors could somehow be increased, this might lead to more small business owners being willing to spend time with business mentees.

\section{LIMITATIONS RELATED TO THIS STUDY}

Although this study meets all applicable criteria for scientific validated research, there are some meaningful limitations that reduce the application of the findings to a generalised context. Specific limitations relate to the following:

The relatively limited sample size indicated specific elements that should be considered when conducting research on business mentor capabilities and willingness to mentor. It identified issues such as race, gender, geographical area, types of business and more, that all contribute to creating a complete picture on the topic. A more complete sample would provide room for extensive factor analysis and other inferential statistical analyses, which would provide better scientific validation of findings and conclusions.

Data on proper representation of race, gender, geographical area, years of business experience, and types of business (industry), business turnover and nature of business mentoring experience would increase the variety of the results.

This study revealed very important elements pertaining to business mentoring capabilities and willingness to mentor that need to be accounted for in the development of small business owners. The quality of the study would have been more complete if it were possible to implement triangulation of measuring mentoring capabilities with additional measuring tools, such as standardised psychological tests. Such $360^{\circ}$ measurement would provide greater insight into the quality of the mentoring capabilities of participating respondents. A combination of qualitative and quantitative study would have delivered more complete, extensive, thorough and probing results.

\section{REFERENCES}

Adams M (2009). Networking and support. In Nieman G, Nieuwenhuizen C. (eds.) Entrepreneurship: A South African Perspective. 2nd ed. Pretoria: Van Schaik.

Albertyn L (2004). Cognitive information-processing perspectives. In: Bergh ZC and Theron AL (eds.) Psychology in the Work Context. 2nd ed. Cape Town: Oxford University Press.

Allen TD, Eby LT, O'Brien KE, Lentz E (2008). The state of mentoring research: a qualitative review of current research methods and future research implications. J. Vocat. Behav. 73:343-357.

Athayde R (2003). Measuring young people's attitudes to enterprise. Kingston. Available: http://www.kingston.ac.uk/sbrc [accessed 21 April 2011].

Audet J, Couteret P, St-Jean E, Laverrière N, Boucher N (2006). Mentoring and Coaching the Entrepreneur: Features and Success Factors. Paper read at the $13^{\text {th }}$ European Mentoring and Coaching Conference, Köln, Germany.

Barrett R (2006). Small business learning through mentoring: evaluating a project. Edu. Train. 48(8/9):614-626.

Benard B (1998). How to be a turnaround teacher/mentor. Resiliency. Available: http://www.resiliency.com/htm/turnaround.htm [accessed 1 
September 2010].

Benn J, Brennand M (2008). Why Mentoring Matters: a Personal Journey that Created Professional Success. Paper read at the New Librarians' Symposium 4, Melbourne. December.

Bergh ZC (2004). Psychopathology. In: Bergh ZC and Theron AL (eds.) Psychology in the Work Context. 2nd ed. Cape Town: Oxford University Press.

Bettmann M (2009). Choosing a research project and a research mentor. J. USA. Heart. Assoc., 119: 1832-1835.

Bozeman B, Feeney MK (2008). Mentor matching: a "goodness of fit" model. Administration. Society 40(5):465-482.

Clutterbuck D (1999). Mentoring in business: executives and directors. Mentoring and Tutoring: Partnership Learn. 6(3):76-84.

Clutterbuck D (2005). Establishing and maintaining mentoring relationships: an overview of mentor and mentee competencies. SA J. Hum. Resourc. Manage. 3(3):2-9.

Cooper DR, Schindler PS (2008). Business Research Methods. International edition. Boston: McGraw-Hill.

Dalley J, Hamilton B (2000). Knowledge, context, learning in the small business. Int. Small Bus. J. 18(3): 51-59.

Department of Statistics (2011). Midyear Population Estimates. Statistical Release (P0302). Pretoria: Government Printer.

Department of Statistics (2012). Quaterly Labour Force Survey. Statistical Release (P0211). Pretoria: Government Printer.

Department of Trade and Industry DTI (1995). White Paper on National Strategy for the Development and Promotion of Small Businesses in South Africa. Government Gazette. 213(16317). Pretoria: Government Printer.

Department of Trade and Industry DTI (2000). National Strategy for Fostering Entrepreneurship Study. Code A. 1.005. Pretoria: Government Printer.

Derrida O (2009). Five qualities of an outstanding business mentor. EzineArticles. Available: http://EzineArticles.com/? expert=Oscar_Derrida [accessed 1 September 2010].

Diamantopoulos AD, Schlegelmilch BB (2000). Taking the fear out of data analysis. Singapore: South-Western Cengage Learning.

Dracup K, Bryan-Brown CW (2004). From novice to expert to mentor: shaping the future. USA J. Crit. Care 13:448-450.

Erasmus BJ, Loedolff PvZ, Mda T, Nel PS (2006). Managing Training and Development in South Africa. 4th ed. Cape Town: Oxford University Press Southern Africa.

Erdem FA, Janset $O$ (2008). Mentoring - a relationship based on trust: qualitative research. Public Personnel Manage. pp.1-6.

Freedman S (2009). Effective mentoring. International Federation of Library Association and Institutions(IFLA) J. 35:171-182.

Gehrke N (1988). Toward a definition of mentoring. Theory into Practice (27)3:190-194.

Ghislieri C, Gatti P, Quaglino GP (2009). Factors affecting willingness to mentor. Int. J. Edu. Vocat. Guid, 9:205-219.

Gibb AA (2000). SME policy, academic research and the growth of ignorance, mystical concepts, myths, assumptions, rituals and confusions. Int. Small. Bus. J. 18(3):13-35.

Hegarty C, Styles J (2008). Using SME intelligence in mentoring science and technology students. Int. J. Technol. Plan. 4(1):20-38.

Herrington M, Kew J, Kew $P$ (2009). Tracking Entrepreneurship in South Africa: A GEM Perspective. Cape Town: UCT Graduate School of Business.

Hisrich RD, Peters MP, Shepherd DA (2008). Entrepreneurship. 7th ed. Boston: McGraw-Hill.

Kelley DJ, Singer S, Herrington M (2012). Global Entrepreneurship Monitor Report. Cape Town: UCT Centre for Innovation and Entrepreneurship.

Ladzani W, Netswera G (2009). Support for rural small businesses in Limpopo province, South Africa. Development SA. 26(2):225-239.
Lamm A, Harder A (2010). Using mentoring as a part of professional development. Available: http://0 edis.ifas.ufl.edu.innopac.up.ac.za/ pdffiles/WC08200.pdf [accessed 1 September].

Lankau MJ, Riordan CM, Thomas CH (2005). The effects of similarity and liking in formal relationships between mentors and protégés. J. Vocat. Behav. 67(1):252-265.

Martin RL (2008). An Investigation into the Knowledge Requirements for Entrepreneur and Small Business Support Practitioners. Unpublished $\mathrm{PhD}$ Entrepreneurship thesis, University of Pretoria.

Mincemoyer CC, Thomson JS (1998). Establishing effective mentoring relationships for individual and organizational success. J. Ext. 36(2):1-3.

Moore CW, Petty JW, Palich LE, Longenecker JG (2008). Managing Small Business: an Entrepreneurial Emphasis. 14th ed. United States: South Western.

National Small Business Amendment Act, No. 29 (2004). Government Gazette 474(27101):1-22.Available: http://www.info.gov.za/gazette/ acts/ 2004/a29-04.pdf [accessed 13 September 2010].

Nieman GH, Nieuwenhuizen C (2009). Entrepreneurship: A South African Perspective. 2nd ed. Pretoria: Van Schaik.

Osif BA (2008). Successful mentoring programs: examples from within and without the academy. J. Bus. Financ. Librariansh. 13(3):335-347.

Pellisier R (2007). Business Research Made Easy. Cape Town: Juta.

Pinho SDC, Coetzee M, Schreuder D (2005). Formal mentoring: mentee and mentor expectations and perceived challenges. SA. J. Hum. Resource. Manage. 3(3):20-26.

Pretorius $M$ (2009). Business failure and turnaround measures. In Nieman G, Nieuwenhuizen C (eds.) Entrepreneurship: A South African Perspective. 2nd ed. Pretoria: Van Schaik.

Rickard K, Rickard A (2009). E-mentoring for small business: an examination of effectiveness. Edu. Train. 51(8/9):747-768.

Robbins SP (2001). Organizational Behavior. 9th ed. New Jersey: Prentice Hall.

Robbins SP, Odendaal A, Roodt G (2006). Organisational Behaviour: Global and South African Perspectives. Cape Town: Pearson Education.

Roythorne-Jacobs H (2004). Leadership. In: Bergh ZC and Theron AL. Psychology in the work context. 2nd ed. Cape Town: Oxford University Press.

Sambunjak D, Straus SE, Marusic A (2009). A systematic review of qualitative research on the meaning and characteristics of mentoring in academic medicine. J. Gen. Int. Med. 25(1):72-78.

Sullivan R (2000). Entrepreneurial learning and mentoring. Int. J. Entrepreneurial. Behav. Res. 6(3):160-175.

Swanepoel E, Strydom JW, Nieuwenhuizen C (2010). An empirical analysis of a private company's corporate social investment in SMME development in South Africa. SA. Bus. Rev. 14(1):58-78.

Terrion JL, Leonard D (2007). A taxonomy of the characteristics of student peer mentors in higher education: findings from a literature review. Mentoring Tutoring 15(2):149-164.

Thompson J, Downing R (2007). The entrepreneur enabler: identifying and supporting those with potential. J. Small. Bus. Enterp. Dev. 14(3):528-544.

Watson GEH (2004). A Situational Analysis of Entrepreneurship Mentors in South Africa. Unpublished M.Comm thesis. University of South Africa. 